\title{
A study of role of brachytherapy IR192 in treatment of eyelid tumors
}

\author{
Manghani $\mathbf{J}^{1}$, Khan $\mathbf{K}^{2}$ \\ ${ }^{1}$ Dr. Jitendra Manghani, Assistant Professor, Department of Ophthalmology, Chirayu Medical College, Bhopal, \\ ${ }^{2}$ Dr. Khalid Khan, People's College of Medical Sciences, Bhopal, MP, India.
}

Address for Correspondence: Dr Jitendra Manghani, Email: roshanchanchlani@ gmail.com

\begin{abstract}
Background: In eye lid cancers, there is a significant risk for tissue damage to nearby vital ocular structures and even of blindness. The skin around the eyelid is thin and contains little subcutaneous tissue and anatomic connections to the underlying bone in the region facilitate rapid local tumor spread into the nasal and orbital cavities. Objective: The aim of this study was to evaluate the response of high dose rate interstitial brachytherapy in carcinoma eye lid. Methodology: From January 2011 to December 2012, 25 diagnosed cases of carcinoma eye lid were reported in our department. All cases were staged clinically according to the TNM staging system. All patients were treated with high dose rate interstitial implant and analyzed for presence of residual disease, local recurrence, distant metastasis, radiation reaction and disease free survival. Result: Total 25 cases were examined, 12 were males while 13 were females. Most of the tumors were involving the lower lid. Squamous cell carcinoma out numbered the basal cell carcinoma. Basal cell carcinoma group of 11 cases, 91\% showed complete regression at 6 months while Squamous cell carcinoma group of 14 cases, 93\% showed total regression. Conclusion: High dose rate interstitial brachytherapy with Iridium 192 is appropriate for the treatment of early staged squamous cell carcinoma of eye lid.
\end{abstract}

Keywords: Brachytherapy, Eyelid, Sebaceous cell carcinoma, Squamous cell carcinoma.

\section{Introduction}

Skin cancers of the eyelid account for $5 \%-10 \%$ percent of all skin cancers. Basal cell carcinoma is the most common eyelid tumor reported in western population and accounts for $90 \%$ of all eyelid malignancies [1]. It most frequently occurs in the lower eyelid (50\%-66\%) and medial canthus $(25 \%-30 \%)$. Although basal cell carcinoma does not metastasize, it may be locally invasive. Surgical excision, Moh's micrographic surgery, cryosurgery, and radiotherapy have all been reported to achieve 5 year cure rates of $90 \%$ or higher in basal cell carcinoma [2], [3].

Squamous cell carcinoma (SCC) and sebaceous cell carcinoma are the common eyelid malignancy in India. Incidence of squamous cell carcinoma has been reported in the literature to account for $2.4 \%-30.2 \%$ of malignant eyelid tumors [4]. It has a predilection for developing at the mucocutaneous junction of the lower eyelid. Unlike basal cell carcinoma of eyelid, squamous

Manuscript received $4^{\text {th }}$ March 2016

Reviewed: $14^{\text {th }}$ March 2016

Author Corrected: $24^{\text {th }}$ March 2016

Accepted for Publication $7^{\text {th }}$ April 2016 cell carcinoma can be an aggressive tumor that has potential to invade the orbit, metastasize to lymph nodes and distant sites, and cause death [4], [5], [6], [7], [8]. Radiation therapy is used for patients who are unwilling or medically unable to undergo an extensive excision of the lesion [9].

Sebaceous cell carcinoma tends to affect patients between the fifth and ninth decades of life. Women are affected at a rate of 2.5 times greater than men. It can originate from meibomian glands and sebaceous glands of the eyelid, eyebrow, and caruncle. Sebaceous cell carcinoma recurs in approximately $9 \%-36 \%$ of patients. It may recur with orbital involvement in $6 \%-17 \%$ of patients. Regional lymph nodes are the most common site of metastases. Distant metastatic site may include the lungs, liver, skull, and brain. The incidence of metastases is approximately $17 \%-28 \%$. The 10 -year tumor death rate is approximately $28 \%$.

In eye lid cancers, there is a significant risk for tissue damage to nearby vital ocular structures and even of 
blindness. The skin around the eyelid is thin and contains little subcutaneous tissue and anatomic connections to the underlying bone in the region facilitate rapid local tumor spread into the nasal and orbital cavities [1], [10], [11]. Early detection is essential, but is often difficult to achieve due to the growth pattern of these tumors, which tend to infiltrate inwards along the deeper layers of the skin and orbital margin. Eyelid tumors often grow under the skin for years before presenting on the surface [1], [10], [11]. Management of any malignant eyelid lesion requires an early and accurate diagnosis followed by total removal of the tumor and reconstruction of the eyelid for restoration of both function and cosmesis.

Our hospital has facility of one HDR remote after loading brachytherapy unit (Microselectron HDR), and a computerized treatment planning system (Plato). This study aimed to evaluate the response of high dose rate interstitial brachytherapy in carcinoma eye lid.

\section{Materials and Methods}

A total of 25 new cases of carcinoma eye lid were reported to department of Ophthalmology and radiotherapy of a tertiary care Institute in central India during January 2011 to December 2012. Histopathological confirmation was done for all patients. All patients were examined and staged clinically according to TNM staging system. All cases were investigated with routine hematological and biochemical examination, X-ray chest, before starting radiotherapy treatment. None of the patient had received prior treatment. Plastic tube technique is used for interstitial implant. In O.T. treatment area was marked on patient. Under general anesthesia rigid hollow stainless steel needles were inserted in to the tumor area parallel to each other in single plane or double plain. The spacing between two needles was $1 \mathrm{~cm}$. Plastic tubes were then threaded in to these hollow needles and left in place to cover the entire target area with subsequent removal of metal needles. The plastic tubes were then secured in close proximity to skin with metallic buttons. After this patient was shifted to brachytherapy treatment room and applicators were connected to Microselectron high dose rate brachytherapy machine through transfer tubes. Treatment planning was done on Plato computerized treatment planning system. Dose was prescribed at 0.5-1 mm depending on thickness of tumor. Fractionated high dose rate radiotherapy was delivered with single high activity 192 Iridium for predetermined time at various dwell position that are $2.5 \mathrm{~mm}$ apart. Total 39 Gy was delivered in six fractions in 6 days. The biological equivalent dose (BED) for tumor was 64.3 Gy and for late responding tissue dose was 123.5 Gy. After completion of brachytherapy applicators were removed under aseptic precaution in operation theatre. No procedural complication was seen.

All the patients were reviewed weekly for one month to observe acute radiation reaction and then monthly for 6 month for assessment of response and treatment related complications. On follow up patients were examined clinically and routine ophthalmic check up was done to see any vision deterioration, lid complication in each patient. The response rates were scored as per WHO guidelines. Complete response was defined as disappearance of all clinical diseases for 1 month after completion of therapy. Partial response and stable disease were defined as $>50 \%$ and $<50 \%$ reduction of tumor size for 1 month after treatment completion, respectively. An increase of tumor size of $>25 \%$ has been considered as progressive disease. Ocular side effects were classified on the basis of the Common Toxicity Criteria manual (version 2.0) and Radiation Therapy Oncology Group / European Organization for Research and Treatment of Cancer (RTOG/EORTC) toxicity criteria.

\section{Result}

Total 25 cases were examined, $12(48 \%)$ were males while $13(52 \%)$ were females. More than $50 \%$ of the patients were above 50 years of age. Most of the tumors were involving the lower lid (Table no.1). In our study Squamous cell carcinoma out numbered the basal cell carcinoma (Fig.1). Most common symptom at the time of presentation was painless nodule in $10(40 \%)$ followed by ulcerated nodule in $8(32 \%)$. Rest $4(16 \%)$ and $3(12 \%)$ were non healing ulcer which bleed on touch and recurrent chalazion respectively. Majority of the cases $18(72 \%)$ were in T3N0M0(>10mm) staging followed by T2NOM0 $(>5-10 \mathrm{~mm})$ in $5(20 \%)$ and T1NOMO $(<5 \mathrm{~mm})$ in $2(8 \%)$. Table no. 2 shows the acute side effects after the brachytherapy. Table no. 3 shows the results of follow up. In Basal cell carcinoma group of 11 cases, $91 \%$ showed complete regression at 6 months and $9 \%$ showed partial regression. There was no recurrence. However in Squamous cell carcinoma group of 14 cases, $93 \%$ showed total regression and $7 \%$ showed partial regression. This group also did not had any recurrence. 
Table No.-1: Site of tumor.

\begin{tabular}{|c|c|c|}
\hline \multirow{2}{*}{ Site } & \multicolumn{2}{|c|}{ Study subject } \\
\cline { 2 - 3 } & No. & 56 \\
\hline Lower lid & 14 & 16 \\
\hline Medial canthus & 4 & 16 \\
\hline Lateral Canthus & 4 & 12 \\
\hline Upper Lid & 3 & \multicolumn{2}{|c|}{} \\
\hline
\end{tabular}

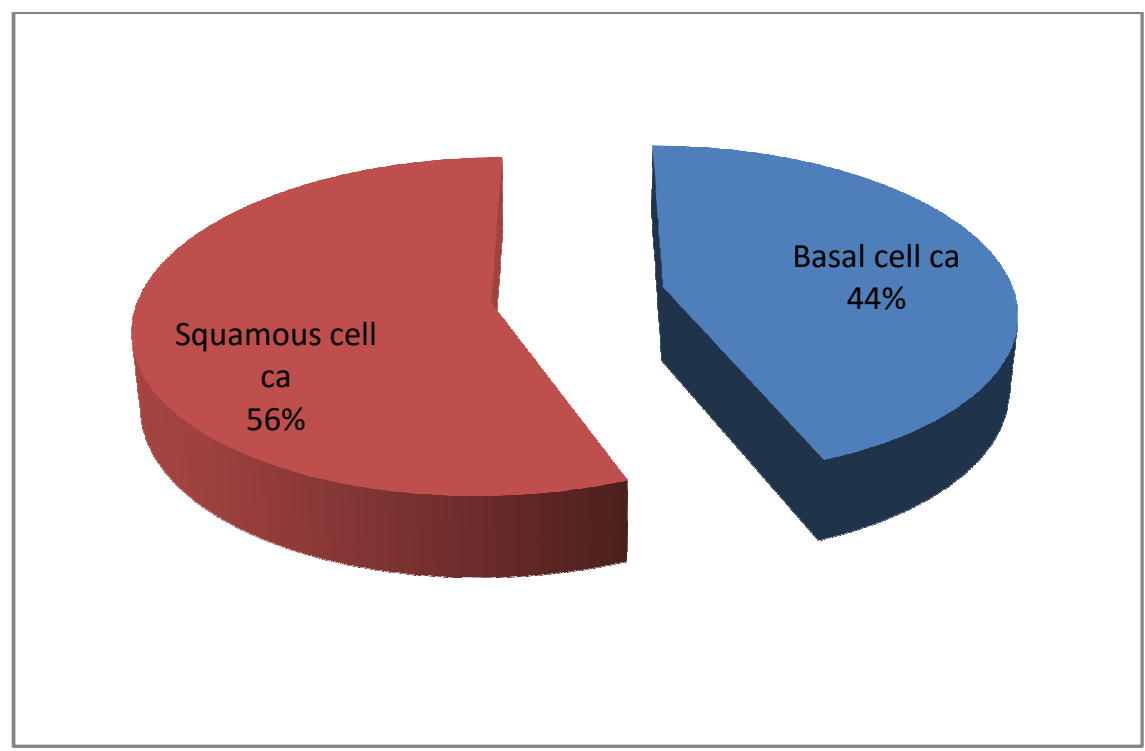

Fig No.-1: Histopathological distribution

Table No.- 2: Acute side effects after the brachytherapy.

\begin{tabular}{|c|c|c|}
\hline \multirow{2}{*}{ Side effect } & No. & Study subject(n=25) \\
\cline { 2 - 3 } & 18 & 72 \\
\hline Erthema and Lid edema & 6 & 24 \\
\hline Falling of eyelashes & 20 & 80 \\
\hline congestion and chemosis & 4 & 16 \\
\hline Corneal erosion and ulcer & & \multicolumn{2}{|c|}{} \\
\hline
\end{tabular}

Table No.-3: Results of follow up.

\begin{tabular}{|c|c|c|c|c|}
\hline Findings & $\mathbf{1}$ month & 3 month & 6 month & $\mathbf{1}$ yrs \\
\hline Persistence of acute side effects & 3 cases & nil & nil & nil \\
\hline Diminuition of vision & nil & nil & nil & nil \\
\hline Cataractous changes & nil & nil & nil & nil nil \\
\hline Fundus changes & nil & nil & nil & nil \\
\hline Functional Impairement & Minimal & Good & Good \\
\hline Cosmetic apperance & Acceptable & Good & Good & Good \\
\hline Patients Satisfaction & Good & nil & &
\end{tabular}




\section{Discussion}

Eyelid cancer is a common problem in the West, representing about $10 \%$ of cancers in the head and neck region. About $59 \%$ of all skin cancers arise in the eyelid and cancers in this location account for at least $11 \%$ of all mortalities from skin malignancies.

The eyelid tumors are fairly common in Indian subcontinent. Sebaceous cell carcinomas of eye lid were more common in females similar to findings of Aurora and Blodi. Lower eyelid was more commonly involved in our study similar to previous studies. BCC was the most common lid cancer encountered in this study, comprising of $44 \%$ of all lid cancer followed by SCC $(56 \%)$.

SCC and sebaceous cell carcinoma has a low incidence rate among white population. $1.5 \%$ of the lid cancer were sebaceous cell carcinoma and has been ranked second in Chinese population. In this study SCC occurred more commonly in males and involved lower lid predominantly, thus correlates with findings that SCC has definite predilection for Lower lid.

BCC is the most common eyelid tumor reported in western population. The literature from Taiwan and Australia also has BCC leading the list. In our study BCC accounted for $44 \%$ of lid cancer.

The treatment of choice for eyelid carcinoma is Moh's micrographic surgery or wide excision with standard frozen section control. Moh achieved the five year cure rates of $99 \%$ in 1773 cases of basal cell carcinoma and of $98.1 \%$ in 213 cases of squamous cell carcinoma of the eyelids and Malhotra reported $71 \%$ control rate in squamous cell carcinoma of eye lid with surgery [2], [3]. However, because of its location, eyelid carcinoma may produce severe dysfunction and can be associated with poor cosmesis after surgical treatment.

Primary radiotherapy was used as an alternative treatment for these eyelid carcinoma by Fitzpatrick et al. and achieved local control rates of 93\%, 97\% [12], [13], [14], [15]. Conill et al. reported $91.6 \%$ local control rate in 24 eye lid tumor with good functional results from high dose rate brachytherapy [16]. Daly et al. reported $97.4 \%$ local control rate in 165 lid cancers with Iridium 192 high dose rate brachytherapy [17]. Fitzpatrick et al. reported a high local control rate (93\%) and excellent cosmetic outcome for patients with SCC of the eyelid who are treated with radiotherapy [12]. In the present study, the local control rate at 6 monthswas $92 \%$ for all lid cancers. The Local control rate at 6 months was $93 \%$ for squamous cell carcinoma and $91 \%$ for basal cell carcinoma of lid with good functional and cosmetic results in present study.

Previous studies have suggested that in patients with eyelid malignancies, primary radiotherapy might be an acceptable alternative to Moh's micrographic surgery in patients who are not great surgical candidates to preserve function and avoid major disfiguring surgery.

The findings of the current study support the concept that radiotherapy is highly effective for treating early staged SCC of the eyelid with acceptable complications.

\section{Conclusion}

From the present study we came to conclusion that high dose rate interstitial brachytherapy with Iridium 192 is appropriate for the treatment of early staged squamous cell carcinoma of eye lid.

Funding: Nil, Conflict of interest: None initiated, Permission from IRB: Yes

\section{References}

1.Cook BE Jr, Bartley GB. Treatment options and future prospects for the management of eyelid malignancies: an evidence-based update. Ophthalmology. 2001 Nov; 108 (11): 2088-98; quiz 2099-100, 2121.

2.Mohs FE. Micrographic surgery for the microscopically controlled excision of eyelid cancers. Arch Ophthalmol. 1986 Jun; 104(6):901-9.

3.Malhotra R, Huilgol SC, Huynh NT, Selva D. The Australian Mohs database: Periocular squamous cell carcinoma. Ophthalmology 2004;111:617-23.

4. Dailey JR, Kennedy RH, Flaharty PM, Eagle RC Jr, Flanagan JC. Squamous cell carcinoma of the eyelid. Ophthal Plast Reconstr Surg. 1994 Sep;10(3): 153-9.

5.Cook BEJr, Bartley GB. Epidemiologic characteristics and clinical course of patients with malignant eyelid tumors in an incidence cohort in 
Olmstead County, Minnesota. Ophthalmology 1999;106:746-50.

6.Doxanas MT, Iliff WJ, Iliff NT, Green WR. Squamous cell carcinoma of the eyelids. Ophthalmology. 1987 May;94(5):538-41.

7.Bowyer JD, Sullivan TJ, Whitehead KJ, Kelly LE, Allison RW. The management of perineural spread of squamous cell carcinoma to the ocular adnexae. Ophthal Plast Reconstr Surg. 2003 Jul;19(4):275-81.

8.Donaldson MJ, Sullivan TJ, Whitehead KJ, Williamson RM. Squamous cell carcinoma of the eyelids. Br J Ophthalmol. 2002 Oct;86(10):1161-5.

9.Rio E, Bardet E, Ferron C, Peuvrel P, Supiot S, Campion L, De Montreuil CB, Mahe MA, Dreno B. Interstitial brachytherapy of periorificial skin carcinomas of the face: a retrospective study of 97 cases. Int J Radiat Oncol Biol Phys. 2005 Nov 1;63(3):753-7. Epub 2005 May 31.

10.Abraham JC, Jabaley ME, Hoopes JE. Basal cell carcinoma of the medial canthal region. Am J Surg. 1973 Oct;126(4):492-5.

11.Collin JR. Basal cell carcinoma in the eyelid region. Br J Ophthalmol. 1976 Dec;60(12):806-9.
12.Fitzpatrick PJ, Thompson GA, Easterbrook WM, Gallie BL, Payne DG. Basal and squamous cell carcinoma of the eyelids and their treatment by radiotherapy. Int J Radiat Oncol Biol Phys. 1984 Apr;10(4):449-54.

13.Lederman M. Radiation treatment of cancer of the eyelids. Br J Ophthalmol. 1976 Dec;60(12):794-805.

14.Faustina M, Diba R, Ahmadi MA, Esmaeli B. Patterns of regional and distant metastasis in patients with eyelid and periocular squamous cell carcinoma. Ophthalmology. 2004 Oct;111(10):1930-2.

15.Schlienger P, Brunin F, Desjardins L, Laurent M, Haye C, Vilcoq JR. External radiotherapy for carcinoma of the eyelid: report of 850 cases treated. Int J Radiat Oncol Biol Phys. 1996 Jan 15;34(2):277-87.

16.Conill C, Molla M, Vilalta A. Brachytherapy with 192Ir as treatment of carcinoma of the tarsal structure of the eyelid. Int J RadiatOncolBiolPhys 2004;59:1326-9.

17.Daly NJ, de Lafontan B, Combes PF. Results of the treatment of 165 lid carcinomas by iridium wire implant. Int J Radiat Oncol Biol Phys. 1984 Apr;10(4):455-9.

\section{How to cite this article?}

Manghani J, Khan K. A study of role of brachytherapy IR192 in treatment of eyelid tumors. Int J Med Res Rev 2016;4(8):1318-1322.doi:10.17511/ijmrr.2016.i08.07. 